\title{
Partitioning effects from ocean and atmosphere on the calving stability of Kangerdlugssuaq Glacier, East Greenland
}

\author{
Poul CHRISTOFFERSEN, ${ }^{1}$ Martin O'LEARY, ${ }^{1}$ Jan H. VAN ANGELEN, ${ }^{2}$ \\ Michiel VAN DEN BROEKE ${ }^{2}$ \\ ${ }^{1}$ Scott Polar Research Institute, University of Cambridge, Cambridge, UK \\ E-mail:pc350@cam.ac.uk \\ ${ }^{2}$ Institute for Marine and Atmospheric Research Utrecht, Utrecht University, Utrecht, The Netherlands
}

\begin{abstract}
We use the $7 \mathrm{~km}$ retreat of Kangerdlugssuaq Glacier (KG), East Greenland, to examine the mechanisms, interactions and relative significance of atmospheric forcing and ice/ocean interactions. Hydrographic data from 1991, 1993 and 2004 show that subtropical waters are common in Kangerdlugssuaq Fjord (KF), and that surface waters were warm in 2004 relative to 1991 and 1993. The main water column was nonetheless warmest in 1991. We contend that while flow of subtropical waters into fjords provides a setting in which rapid glacier retreat can occur, the triggering of retreat depends on additional environmental factors. The climatic variables standing out in our study of KG and KF are air temperature and katabatic winds. Both had strong positive anomalies during winter 2004/05, when KG retreated. We show that proglacial ice melange was absent and that fjord freeze-up did not occur until 11 April 2005, due to warm and windy conditions. We demonstrate that this setting is unusual and hypothesize that exposure to open water in winter months caused the retreat. Calculation of ice-front melt rates shows that discharge of basal meltwater, first from runoff and subsequently from frictional basal heating, should intensify the interaction between glacier and fjord.
\end{abstract}

\section{INTRODUCTION}

The Greenland ice sheet is losing mass at rates of 150 $250 \mathrm{Gta}^{-1}$ (Rignot and others, 2008; Van den Broeke and others, 2009) and there is growing concern that this rate will increase because of climate change (Solomon and others, 2007). Fuelling these concerns are mass budget estimates showing a decreasing trend of the surface mass balance $\left(-13 \mathrm{Gta}^{-2}\right)$ due to a steady increase in surface runoff, as well as increasing discharge of ice to the ocean $\left(9.0 \mathrm{Gt} \mathrm{a}^{-2}\right)$ by ocean-terminating outlet glaciers (Rignot and others, 2011). Increased runoff is directly related to atmospheric forcing (Ettema and others, 2010), and there is good overall consistency between estimates of runoff from different types of models (Bougamont and others, 2007). The quantity of ice discharged to the ocean through fjord-terminating outlet glaciers, i.e. tidewater glaciers, varies less than runoff, but is problematic because glacier dynamics affect the mass budget of ice sheets on timescales ranging from years to many decades (Price and others, 2011).

Kangerdlugssuaq Glacier (KG), East Greenland, is one of the largest tidewater glacier systems in the world. During its well-documented retreat of $7 \mathrm{~km}$ between July 2004 and April 2005 (Joughin and others, 2008a; Seale and others, 2011), the glacier doubled its speed from $20 \mathrm{~m} \mathrm{~d}^{-1}$ to $40 \mathrm{~m} \mathrm{~d}^{-1}$ (Luckman and others, 2006; Howat and others, 2007). This speed change resulted in a loss of $80 \mathrm{Gt}$ of ice between September 2004 and January 2008 (Howat and others, 2011). This is $\sim 350 \%$ higher than the loss would have been if it had occurred at the pre-retreat rate $\left(\sim 6.5 \mathrm{Gta}^{-1}\right)$. Although net annual losses returned to lower rates after $2008\left(\sim 10 \mathrm{Gta}^{-1}\right)$, the immediate loss is only the beginning of the ice sheet's dynamical contribution to higher sea levels. Price and others (2011) show that by 2100 the long-term mass loss from slow diffusive thinning could be three times that of the glacier's immediate response.
The abrupt retreat of KG and other Greenlandic tidewater glaciers during the last decade was first thought to be due to increased runoff caused by atmospheric warming (Rignot and Kanagaratnam, 2006). But whereas air temperature and ice-sheet runoff continued to increase in the 2000s, the glaciers have been more stably positioned since 2005 (Howat and others, 2007; Murray and others, 2010). The dynamic change is now thought to be due to subtropical waters, flowing into fjords via coastal currents. Straneo and others (2010) show that circulation in Sermilik Fjord is strongly influenced by high wind speed during intermittent storms. Christoffersen and others (2011) show that winds are also important on a synoptic scale and that the position of the Icelandic low, a semi-permanent atmospheric lowpressure system in the North Atlantic, has a strong effect on the transport of subtropical water towards Greenland.

Although the transport of subtropical waters into Greenland fjords is far from simple, a characteristic behaviour is seen in the recent widespread change of Greenlandic tidewater glaciers. Seale and others (2011) show that glaciers flowing into East Greenland fjords south of $69^{\circ} \mathrm{N}$ experienced widespread retreat in 2000-05, whereas glaciers in fjords north of this latitude experienced little or no retreat during the same period. This relatively sharp boundary of glaciological behaviour is not related to atmospheric conditions, but to the presence (south) and absence (north) of warm subtropical water from the Irminger Sea.

Here we use the well-documented retreat of KG in 2004/ 05 and observations from within and near KF to partition effects from the glacier's interactions with atmosphere and ocean. Although the retreat occurred when the fjord contained relatively warm water, we document warmer properties in a previous year when the glacier remained relatively unchanged. While flow of subtropical waters into fjords provides a setting in which rapid glacier retreat can occur, the triggering of retreat seems to depend on 

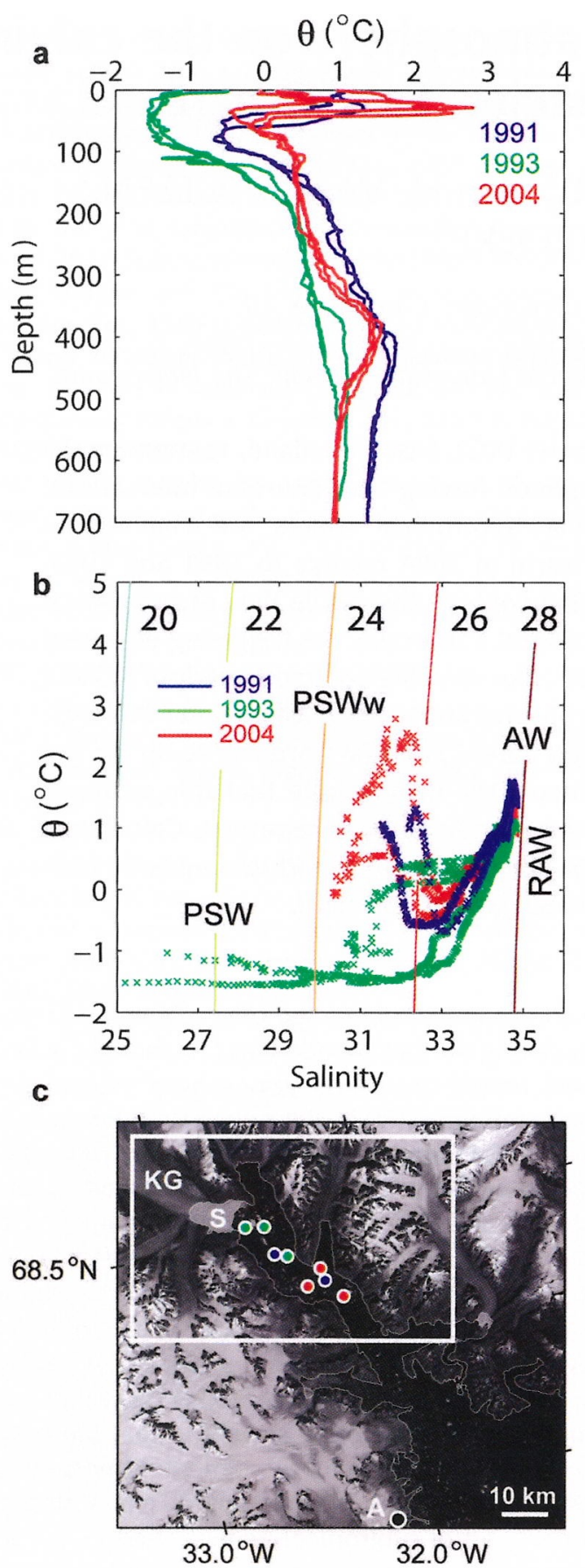

Fig. 1. (a) Potential temperature profiles from conductivitytemperature-depth measurements in upper KF. Blue, green and red lines denote measurements from 1991, 1993 and 2004, respectively. (b) Plot showing potential temperature and salinity of water masses. PSW is polar surface water, PSWw is warm polar surface water, AW is Atlantic water and RAW is recirculating Atlantic water. Colour denotation is identical to (a). Numbers 20 28 refer to $\sigma_{t}=(\rho-1000) \mathrm{kg} \mathrm{m}^{-3}$ where $\rho$ is density. (c) Landsat image from 16 August 2002 showing KG and its proglacial sikussak (S). The coloured dots show approximate station locations for measurements shown in (a) and (b). White box outlines subset of MODIS scenes shown in Figure 4.

additional factors. The climatic factors that stand out are air temperature and katabatic winds during winter months. We show that proglacial ice melange was absent during the retreat and that the fjord did not freeze-up until 11 April 2005 because of warm and windy conditions. The exposure to open water prolonged the period when calving occurs at a high rate, resulting in significant retreat, speed-up and intensified interaction with fjord waters.

\section{KANGERDLUGSSUAQ FJORD}

\section{Environment and setting}

Kangerdlugssuaq Fjord (KF) is $70 \mathrm{~km}$ long and $5-10 \mathrm{~km}$ wide (Fig. 1). Water depths range from $450 \mathrm{~m}$ over a sill $10 \mathrm{~km}$ from $\mathrm{KG}^{\prime} \mathrm{s}$ calving front to $870 \mathrm{~m}$ near the mouth $\left(68.1^{\circ} \mathrm{N}\right.$, $31.9^{\circ} \mathrm{W}$ ) (Dowdeswell and others, 2010). Icebergs are the main freshwater source in the fjord due to the high rate of discharge from KG, currently 30 Gta ${ }^{-1}$ (Howat and others, 2011). The fjord is typically ice-free between July and December, and ice-covered from January to June. An area extending $\sim 5 \mathrm{~km}$ from the front of KG comprises a semipersistent melange of icebergs and shore-fast sea ice known as sikussak (Fig. 1C) (Syvitski and others, 1996; Dowdeswell and others, 2010).

\section{Fjord waters}

The bathymetry of KF and the properties of fjord waters have been established from scientific cruises in September 1993 (Azetsu-Scott and Syvitski, 1999) and September 2004 (Dowdeswell and others, 2010; Christoffersen and others, 2011). Here we use these datasets together with additional data from an earlier cruise in September 1991 (Andrews and others, 1994). Two important water masses inside the fjord are polar surface water (PSW) and subtropical Atlantic water (AW) (Fig. 1), with properties governed by the corresponding water masses found in the East Greenland Current and the Irminger Sea (Sutherland and Pickart, 2008). PSW in the upper fjord has low salinity $(S<32 \mathrm{psu})$ but variable temperature. The potential temperature, $\theta$, was up to $1.3^{\circ} \mathrm{C}$ in 1991 and up to $2.8^{\circ} \mathrm{C}$ in 2004 , therefore falling into the category referred to as 'warm' PSW (PSWW) (Rudels and others, 2002). PSW in 1993 was fresh as well as cold $\left(-1.5^{\circ} \mathrm{C}\right)$ (Fig. 1a). The salinity, $S$, of AW is high $(S \sim 34.9$ psu), and potential temperature in the upper fjord was $\sim 1.8^{\circ} \mathrm{C}$ in 1991 and $\sim 1.5^{\circ} \mathrm{C}$ in 2004. AW in 1993 was colder $\left(<1.1^{\circ} \mathrm{C}\right)$, suggesting it was recirculating AW from the Nordic Seas, i.e. RAW when using the water mass class of Rudels and others (2002), rather than the warmer AW from the Irminger Sea. The $\theta-S$ composition of the different water masses is shown in Figure $1 \mathrm{~b}$.

A third important water mass is the deeper ambient fjord water, which was warm in $1991\left(\theta \sim 1.4^{\circ} \mathrm{C}\right)$ relative to 1993 as well as 2004 (Fig. 1). The temperature difference of $<0.4^{\circ} \mathrm{C}$ suggests more vigorous mixing with $\mathrm{AW}$ or that it was formed by warm AW from the Irminger Sea rather than the colder RAW.

\section{Atmospheric conditions}

The atmospheric conditions in $\mathrm{KF}$ are seen in the station record from Aputiteq at the western side of KF mouth, $\sim 80 \mathrm{~km}$ from KG (see Fig. 1c for location). Figure 2 shows mean monthly air temperature in 1987-2008, together with seasonal averages for the extended summer (June-September) and winter (December-March) periods. The extended periods are used because the inclusion of June and March helps identify summer and winter characteristics. Although the temperature record from Aputiteq is not complete, we use it because of its close proximity to KF and KG. To fill the 


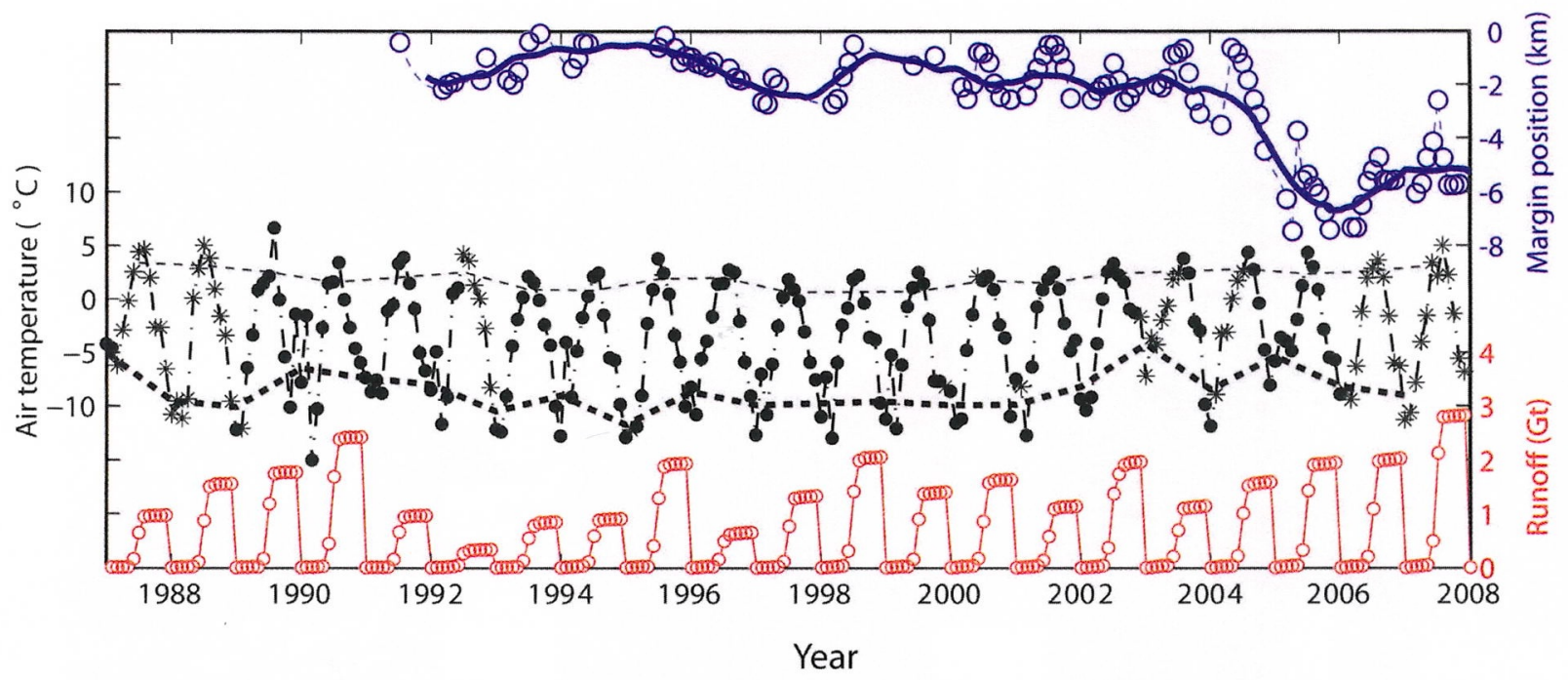

Fig. 2. Plot showing changes in the position of KG's calving front (open blue circles); mean monthly air temperature, as measured in Aputiteq (solid black dots) or as represented in the ERA-Interim climatology (black asterisk); and runoff in the KG drainage basin (open red circles). The bold blue line shows the 12 month moving average of mean monthly frontal positions; the thin dashed line in black shows mean summer air temperatures averaged for June-September; and the bold dashed line in black shows mean winter air temperatures averaged for December-March.

missing data points, we use surface air temperature from the equivalent location in the European Centre for MediumRange Weather Forecasts Interim Re-analysis (ERA-Interim) climatology (Simmons and others, 2006) (Fig. 2). A good correlation $(r=0.92)$ for the overlapping data $(n=182)$ shows that this procedure is satisfactory (data not shown). Between 1997 and 2008, mean summer temperatures increased gradually from $-1.3^{\circ} \mathrm{C}$ below the period mean $\left(\sim 2.0^{\circ} \mathrm{C}\right)$ to an anomaly of $+1.2^{\circ} \mathrm{C}$. The mean winter air temperature differs in that two very large peaks occurred: one in $2002 / 03\left(+4.3^{\circ} \mathrm{C}\right)$, the other in $2004 / 05\left(+3.1^{\circ} \mathrm{C}\right)$.

Melting of ice is controlled by the surface energy budget and not simply air temperature. We therefore calculate the cumulative runoff in the Kangerdlugssuaq drainage basin using outcomes from the RACMO2.1/GR regional atmospheric climate model, adapted from the Royal Netherlands Meteorological Institute (KNMI) regional climate model RACMO2.1 (Van Meijgaard and others, 2008) and extended with a multilayer snow model to better represent the conditions on Greenland (Ettema and others, 2010). The runoff was very close to the period mean in 2004, when KG started its rapid retreat (Fig. 2).

\section{ICE/OCEAN INTERACTIONS}

An explicit cause of the KG retreat is not found in the runoff calculated in RACMO. This implies that retreat did not occur because surface meltwater production was high (as shown earlier by Luckman and others, 2006). Furthermore, the hydrographic data from 1991 show that the presence of warm water in KF does not necessarily result in a rapid glaciological response. The lack of response of $\mathrm{KG}$ to warm fjord conditions in 1991 is corroborated by a Landsat image acquired on 21 June 1991 (Fig. 2) and other Landsat scenes dating back to 1978 (Dwyer, 1995). The climatic variable that stands out during the retreat is the mean winter air temperature in 2004/05, which was the second highest anomaly in the period investigated (1987-2008). While warm AW in fjords clearly provides a setting in which rapid retreat can occur, the retreat of KG may have occurred because warm atmospheric conditions intensified the interaction between the glacier and the fjord waters. Below we discuss this further.

\section{The atmospheric effect}

The atmospheric conditions near KF in 2004/05 are seen in Figure 3 together with the front position of KG during its prolonged retreat. The warm surface conditions during the retreat, which started in July 2004 and lasted 10 months, are clearly visible as an increasing trend in air temperature between December 2004 and March 2005. The daily mean temperature occasionally exceeded $0^{\circ} \mathrm{C}$ during this warm winter. The temperature anomaly is $\sim 2 \sigma$ and therefore unusual. The retreat was unusual, not because it was fast (the rate of retreat was similar to other years), but because it lasted 10 months and continued throughout the winter months (December-March) and well into April 2005 (Joughin and others, 2008a), i.e. it was prolonged compared to other years. The transition from retreat to advance typically occurs in January or February (Luckman and others, 2006; personal communication from A. Luckman, 2011).

The margin positions shown in Figure 3 were derived from an automated method utilizing the high (daily)

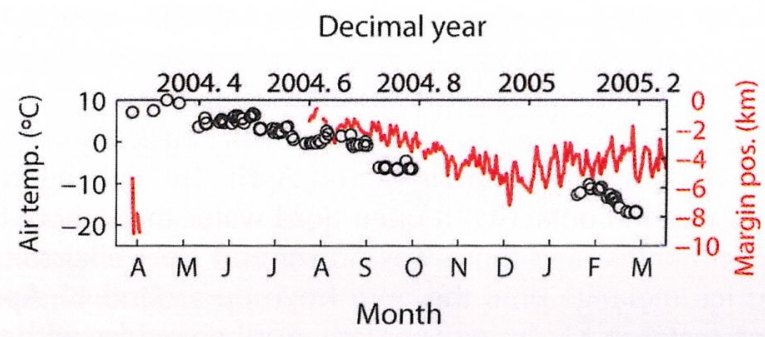

Fig. 3. Plot showing variation in daily air temperature in Aputiteq (solid red line) and positions of $\mathrm{KG}^{\prime}$ 's calving ice front during the retreat in 2004/05 (open black circles), as seen in daily MODIS imagery. Data are plotted from April to next March. 

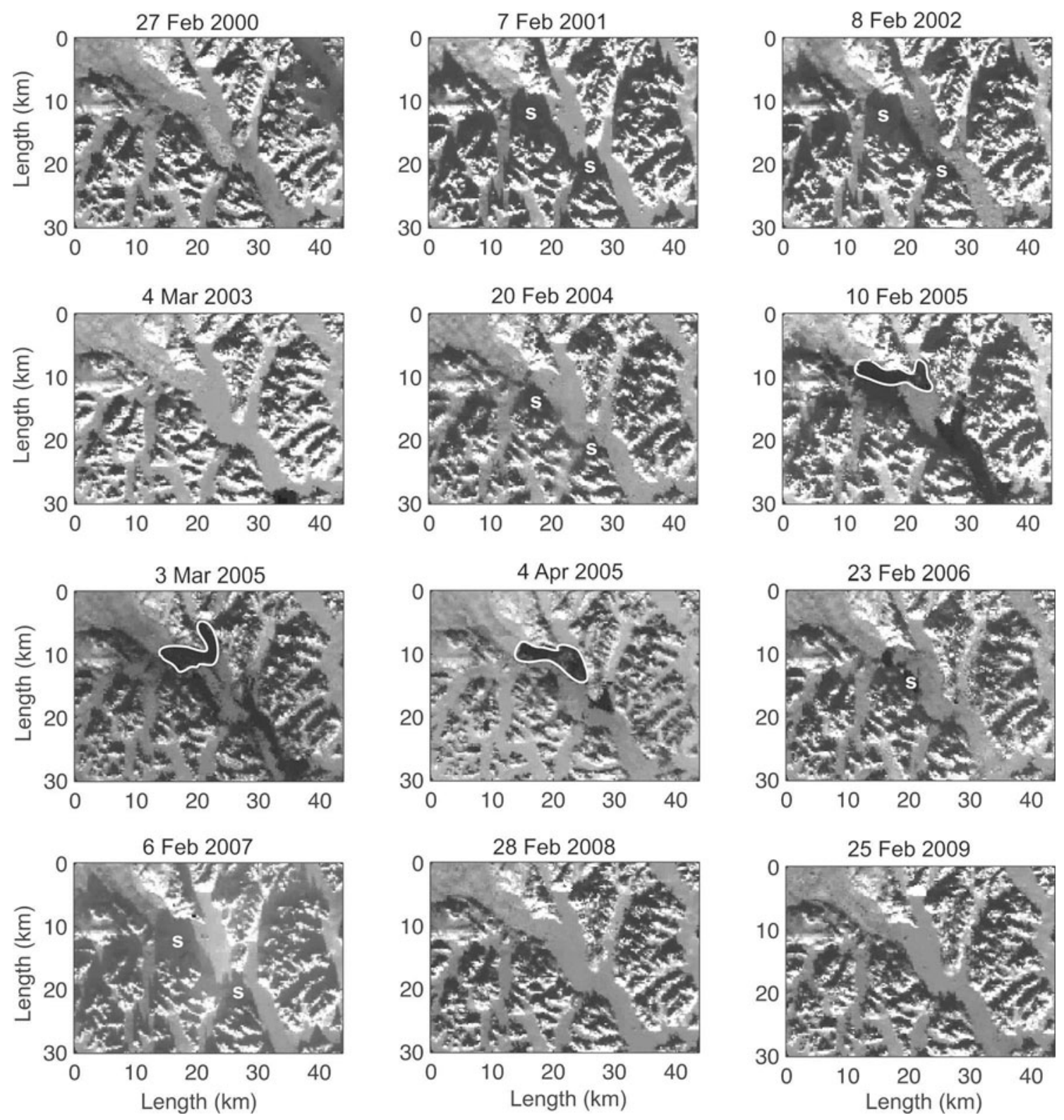

Fig. 4. Subsets of MODIS scenes illustrating sea-ice conditions in KF. The image sequence shows that freeze-up in the fjord typically takes place prior to the return of solar illumination in February. The exception is winter 2004/05, when freeze-up did not occur until 11 April 2005. Solid white lines outline coastal polynya in front of KG. ' $S$ ' denotes effect of shadow. An animation of the MODIS subset is available in the auxiliary material of Seale and others (2011).

temporal resolution of Moderate Resolution Imaging Spectroradiometer (MODIS) imagery (Seale and others, 2011). Subsets of MODIS scenes illustrating sea-ice conditions in KF are shown in Figure 4. The image sequence shows that sea-ice conditions in February-April 2005 were unusual relative to other years in the MODIS record. The fjord is typically covered by shore-fast sea ice in February, when solar illumination returns after a blackout period. In 2005, however, there was an absence of sea ice and even sikussak between 4 February and 4 April. The calving front of KG was in contact with open fjord water throughout the winter months, and there was no support from sikussak or rigid ice melange until the fjord froze up around 11 April. Open water in KF during February-April coincides with the retreat of KG and is, as far as we know, a rare occurrence.

The two principal factors governing the formation of polynya in regions of shore-fast sea ice are air temperature and wind speed. We have already shown that the mean winter air temperature anomaly in 2004/05 was positive and high $\left(+3.1^{\circ} \mathrm{C}\right)$. This seasonal anomaly is primarily a result of very warm atmospheric conditions in February and March 2005, when the anomaly exceeded $+5^{\circ} \mathrm{C}$. (December 2004 was cold relative to the December mean.) Because February and March is the main period of sea-ice formation and because the monthly anomaly was high relative to the monthly means $\left(-8\right.$ to $-9^{\circ} \mathrm{C}$ ), we expect that a decreased rate of sea-ice formation from high air temperature contributed to the formation of the proglacial polynya.

The second factor responsible for polynya formation is wind speed, and our data show that winds may also have influenced the polynya in front of KG. Figure 5 shows $10 \mathrm{~m}$ winds from RACMO2.1/GR averaged from December to March. The seasonally averaged wind speeds in 2004/05 are $\sim 4 \mathrm{~m} \mathrm{~s}^{-1}$ in KF and up to $\sim 8 \mathrm{~m} \mathrm{~s}^{-1}$ over the upper part of $\mathrm{KG}$. The directional constancy is close to 1 , which indicates that winds are governed almost exclusively by the katabatic 

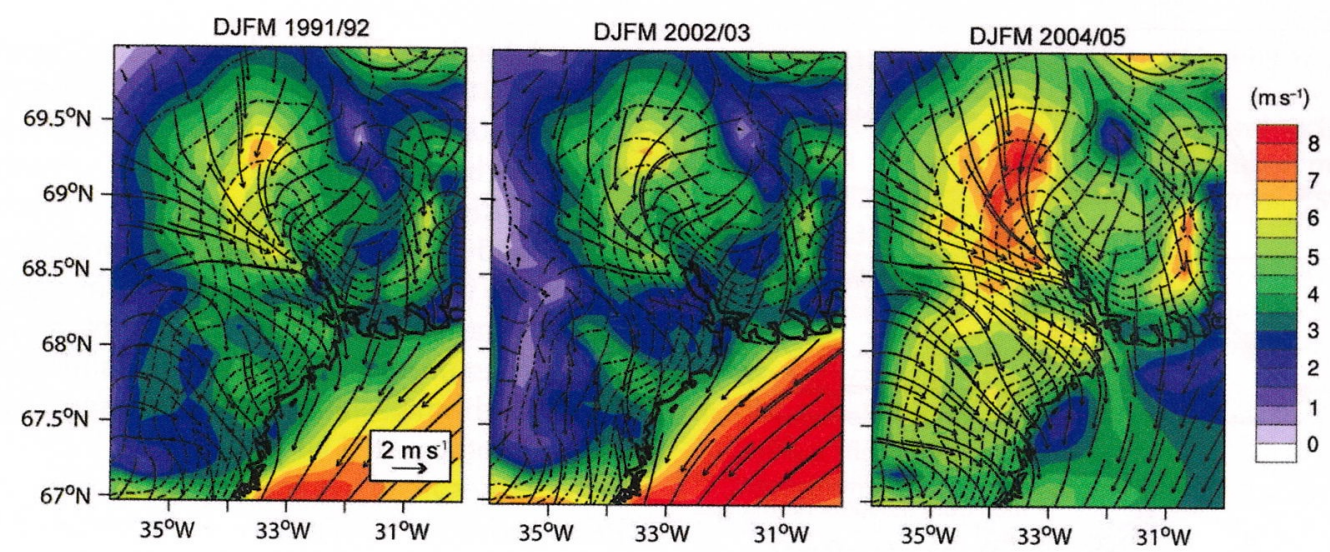

Fig. 5. Maps showing direction and speed of $10 \mathrm{~m}$ winds from RACMO2.1/GR when averaged from December to March in $1991 / 92$ (left), 2002/03 (middle) and 2004/05 (right). The winds are predominantly katabatic, and the strongest katabatic pressure gradient force is found over KG.

pressure gradient force, which is strong in winter due to surface cooling and the absence of solar radiation (Van Angelen and others, 2011). The katabatic winds were much weaker in 2002/03 (Fig. 5), the only other winter in our record with higher air-temperature anomaly $\left(+4.3^{\circ} \mathrm{C}\right)$. This may explain why a coastal polynya did not form at this point in time. In winter 1991/92, when warm water was also present in the fjord, the mean air temperature was $+1.1{ }^{\circ} \mathrm{C}$, but runoff reached only $0.97 \mathrm{Gt}$, compared to $1.6 \mathrm{Gt}$ in 2004. The katabatic winds during this winter were furthermore weak (Fig. 5).

\section{The glaciological effect}

We have shown that warm atmospheric conditions and strong winds in winter 2004/05 caused open water to form in front of KG, and that prolonged retreat, lasting until April 2005, occurred under this unusual condition. Previous studies show that seasonal strengthening of sikussak or ice melange may suppress the calving rate (Reeh and others, 2001), helping tidewater glaciers to advance in winter (Sohn and others, 1998; Joughin and others, 2008a; Amundson and others, 2010). For Jakobshavn Isbræ, this advance is accompanied by reduced speeds due to changes in geometry and stress distribution, with the additional effect of increasing friction along the fjord side-walls (Joughin and others, 2008b; Amundson and others, 2010). The advance and retreat of other glaciers in West Greenland show similar correspondence to proglacial sea-ice conditions (Howat and others, 2010). The same but opposite effect may explain why KG doubled its speed in 2004/05, when a prolonged period of active calving caused the front to retreat by $7 \mathrm{~km}$ (Fig. 3). While this inferred mechanical influence of rigid proglacial ice melange on calving is consistent with previous studies, it does not explain why significant calving retreat occurred mainly in a region where fjords contain warm AW (Seale and others, 2011). The latter implies an interaction with fjord waters.

The link between KG and the ocean during its retreat may lie in a large input of subglacial meltwater to the proglacial environment, as speed-up caused increased frictional heating at the bed. Since the speed-up occurred in winter, this additional water would have entered the fjord when the basal water system did not carry surface meltwater. Very little is known about the basal environment of $\mathrm{KG}$, but a simple calculation of the basal heat budget based on information from similar glaciers nonetheless indicates that a large meltwater volume was produced by the speed change. The basal heat budget is $G+\tau U-K \partial T / \partial z-\rho \dot{m} L$ $=0$, where $G$ is the geothermal heat flux; the second term is frictional heat, calculated from basal drag, $\tau$, and velocity, $U$; the third term is the conductive heat loss, calculated from basal ice temperature gradient, $\partial T / \partial z$, and the thermal conductivity of ice, $K$; and the fourth term is latent heat of fusion, calculated from ice density, $\rho$, the basal melt rate, $\dot{m}$, and the coefficient for latent heat of fusion, $L$ (Christoffersen and Tulaczyk, 2003). The basal drag of KG is not known, so we assume it is of similar magnitude to the drag calculated for Jakobshavn Isbræ, $\sim 200 \mathrm{kPa}$ (Iken and others, 1993; Funk and others, 1994). With speeds $\sim 20 \mathrm{~m} \mathrm{~d}^{-1}$ or higher, frictional heat would be around two orders of magnitude higher than $G$ as well as $K \partial T / \partial z$, suggesting that $\tau U=\rho \dot{m} L$ is a reasonable approximation of the heat budget. Basal melting up to several metres per year may have occurred beneath the lower part of the glacier where the speed is highest, and, with speed change occurring over a distance of $>30 \mathrm{~km}$ (Howat and others, 2007), increased frictional heating could have increased the discharge of basal meltwater by $\sim 1 \mathrm{~km}^{3} \mathrm{a}^{-1}$ when speeds peaked.

There are two ways in which meltwater from increased frictional heating could have affected the flow and dynamics of KG. The first is an increase in basal lubrication, and the second is an increase of calving in response to plumeinduced ice-front melting. Nick and others (2009) show that the speed change of Helheim Glacier in 2000-05 is consistent with a prescribed retreat of the calving ice front rather than basal lubrication, so we assume that the latter is more likely. To illustrate this, we use melt estimates based on a simple convection-driven model of plume flow and velocity-based parameterizations of melt similar to those underneath Antarctic ice shelves (Jenkins and others, 2010). A full description of this model is beyond the scope of this study. We therefore refer to O'Leary (2011) who shows that this model can be applied to tidewater glacier fronts, yielding results consistent with observations from West Greenland. These melt rates include strong dependencies on both ocean temperature and stratification. The flux of water in the subglacial water system beneath the glacier is also important, as shown by Jenkins (2011), as the rate of frontal melting has a cube-root dependence on the subglacial discharge to the fjord. Here we apply a model similar to that 

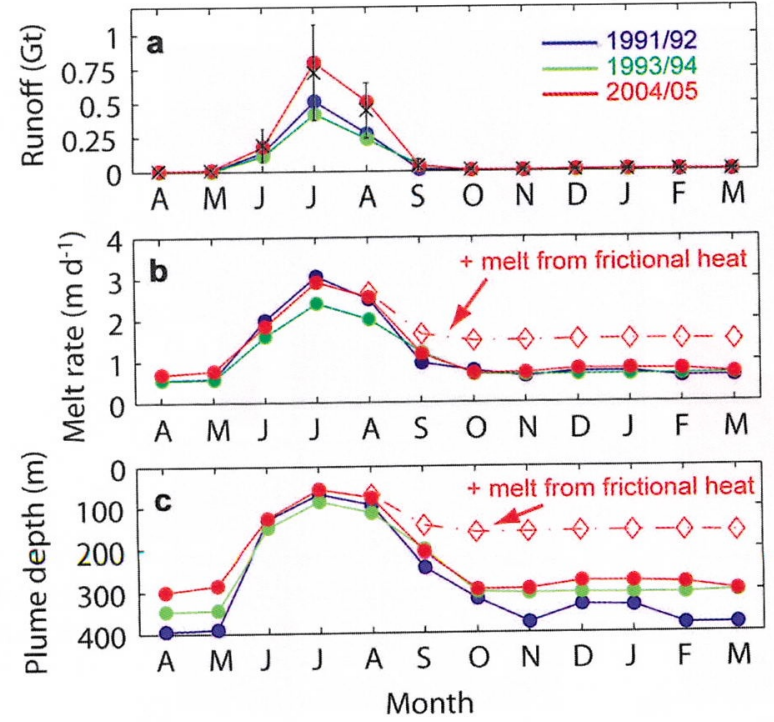

Fig. 6. Plots showing (a) runoff in the Kangerdlugssuaq drainage basin from RACMO2.1/GR, (b) maximum rates of ice-front melting calculated with plume model, and (c) depth of plume when reaching neutral buoyancy with ambient fjord water. Blue, green and red dots mark data for 1991, 1993 and 2004, respectively. Data are plotted from April to next March.

used by Jenkins (2011) to KG, assuming that its ice front is $\sim 600 \mathrm{~m}$ high. Using hydrographic data from 1991, 1993 and 2004, as shown in Figure 1, and runoff, as shown in Figure $6 \mathrm{a}$, we estimate plume-induced ice-front melting at rates up to $3 \mathrm{md}^{-1}$ in the melt season (Fig. 6b). When frictional melting beneath the glacier is excluded, the melt rate on the ice front drops to low values in winter months, when runoff does not feed the subglacial water system. We find the highest melt rate in July 1991 because fjord waters at depths greater than $400 \mathrm{~m}$ were $0.4^{\circ} \mathrm{C}$ warmer than in 1993 and 2004 (Fig. 6b). The melt rate in July 2004 is nevertheless almost as high because runoff in July 2004 was $0.80 \mathrm{Gt}$ compared to $0.42 \mathrm{Gt}$ in July 1993 and $0.51 \mathrm{Gt}$ in July 1991 (Fig. 6a).

When melting from frictional heat released during the speed-up is included in the model, we find little effect in summer months because the flux of meltwater from the basal water system is already high due to runoff. The effect is proportionally higher in winter, when runoff is nil. With frictional meltwater added, the winter melt rate doubles from $\sim 0.7 \mathrm{~m} \mathrm{~d}^{-1}$ to $\sim 1.5 \mathrm{~m} \mathrm{~d}^{-1}$ (Fig. 6b). We also find that the plume becomes substantially more buoyant when frictional basal melting is included. The depth of neutral buoyancy with the surrounding fjord water increases from $>280 \mathrm{~m}$ to $<160 \mathrm{~m}$ (Fig. 6c). The speed-up of KG due to its retreat may thus have prolonged the period of strong ice/ ocean interactions.

\section{SUMMARY AND CONCLUSIONS}

The flow of tidewater glaciers in Greenland is influenced by ocean as well as atmosphere, but the significance of these forcings relative to each other is not well understood. Furthermore, whereas tidewater glaciers according to the classic theory should respond to climate change through the alteration of mass balance, i.e. indirectly, the Greenland-type tidewater glacier differs in that it responds sensitively to external forcing. The sudden increase in discharge from Greenland tidewater glaciers in the early 2000s was originally thought to be a response to atmospheric warming, which was sustained in the southeast where many glaciers retreated (Rignot and others, 2004; Howat and others, 2008; Murray and others, 2010). Recent studies have shown that this region is also influenced by warm subtropical waters, entering coastal currents and fjords after transportation to the Irminger Sea from the Atlantic (Holland and others, 2008; Murray and others, 2010; Christoffersen and others, 2011; Seale and others, 2011).

The widespread recent retreat of tidewater glaciers in Greenland offers a window of opportunity to identify the relevant environmental forcing. While warm subsurface conditions in KF were a significant factor in the retreat of $\mathrm{KG}$ (Christoffersen and others, 2011), additional data show that KG remained relatively unaffected by warm subsurface conditions in 1991. The driver of warm subsurface conditions in 1991 is the same as that causing warm subsurface conditions in 2004, i.e. a western position of the Icelandic low, inducing weak northeasterly airflow along East Greenland and inflows of AW from the Irminger Sea towards the coast (Christoffersen and others, 2011). The cold subsurface conditions in 1993 were a consequence of colder and stronger winds from the northeast, occurring when the Icelandic low has an eastern position. Periods when synoptic atmospheric conditions in the North Atlantic caused coastal warming offshore of KF include 1985-87, 1991-92, 1996 and 2001-06 (Christoffersen and others, 2011).

The warm subsurface conditions observed in KF in 1991 show that tidewater glaciers do not necessarily retreat when fjords are warm. We therefore contend that while warm AW in fjords provides a setting in which rapid glacial retreat can occur, the triggering of retreats depends on additional factors. The climatic factors that stand out in this study of KG and KF are winter air temperature and katabatic winds, which both have strong positive anomalies when averaged from December 2004 to March 2005, the period when KG retreated by more than twice its seasonal average. Satellite images show that freeze-up of the fjord did not occur until 11 April 2005, which is about 3 months later than any other year examined. We attribute the ice-free condition to (1) reduced sea-ice production due to mild air temperature, and (2) transport of sea ice away from the calving front by strong katabatic winds.

We have shown that a plume fed by ice-sheet runoff should melt the front of $\mathrm{KG}$ at rates up to $3 \mathrm{md}^{-1}$, but this rate should drop to small values in winter, when the subglacial drainage system does not carry surface meltwater. However, the plume may have remained active in winter 2004/05, with melt rates around half those in summer, due to meltwater produced by frictional heating associated with the glacier's speed-up. The latter occurred because the calving front retreated, as demonstrated by Nick and others' (2009) modelling of Helheim Glacier, and the retreat was a result of ice-free conditions, which prolonged the period of fast calving and strong ice/ocean interactions.

Our study of KG and KF implies that tidewater glaciers in Greenland may respond sensitively to the combined effect of oceanic and atmospheric warming. Whereas the ocean effect is modulated by the North Atlantic Oscillation (NAO; Holland and others, 2008; Christoffersen and others, 2011), a recurring regional pattern of atmospheric variability, the latter is directly related to climate change. We conclude by hypothesizing that tidewater glaciers will become (or have 
become) more sensitive to warming of fjords after periods of weak NAO because atmospheric warming is intensifying and prolonging their interactions with fjord waters. A potentially important aspect not included in this study is the long-term effect of mass imbalance. Thomas and others (2000) report thinning of KG by $\sim 50 \mathrm{~m}$ in 1995-98, and Howat and others (2011) show that the glacier was losing mass at a rate of $\sim 6.5 \mathrm{Gta}^{-1}$ in 2000 . It is possible that thinning in the 1990s and early 2000s caused the ice front to become less stable and more susceptible to retreat.

\section{ACKNOWLEDGEMENTS}

This study was funded by research grant NE/G00692X/1 awarded by the UK Natural Environment Research Council. The authors are grateful to the scientific editor, Ted Scambos, and two anonymous reviewers.

\section{REFERENCES}

Amundson JM, Fahnestock M, Truffer M, Brown J, Lüthi MP and Motyka RJ (2010) Ice mélange dynamics and implications for terminus stability, Jakobshavn Isbræ, Greenland. J. Geophys. Res., 115(F1), F01005 (doi: 10.1029/2009JF001405)

Andrews JT, Milliman JD, Jennings AE, Rynes $N$ and Dwyer JL (1994) Sediment thicknesses and Holocene glacial marine sedimentation rates in three East Greenland fjords $\left(\right.$ ca. $\left.68^{\circ} \mathrm{N}\right)$. J. Geol., 102(6), 669-683

Azetsu-Scott K and Syvitski JPM (1999) Influence of melting icebergs on distribution, characteristics and transport of marine particles in an East Greenland fjord. J. Geophys. Res., 104(C3), 5321-5328 (doi: 10.1029/1998JC900083)

Bougamont $M$ and 7 others (2007) Impact of model physics on estimating the surface mass balance of the Greenland ice sheet. Geophys. Res. Lett., 34(17), L17501 (doi: 10.1029/ 2007GL030700)

Christoffersen P and Tulaczyk S (2003) Response of subglacial sediments to basal freeze-on: I. Theory and comparison to observations from beneath the West Antarctic ice sheet. J. Geophys. Res., 108(B4), 222 (doi: 10.1029/2002JB001935)

Christoffersen P and 7 others (2011) Warming of waters in an East Greenland fjord prior to glacier retreat: mechanisms and connection to large-scale atmospheric conditions. Cryosphere, 5(3), 701-714 (doi: 10.5194/tc-5-701-2011)

Dowdeswell JA, Evans J and Ó Cofaigh C (2010) Submarine landforms and shallow acoustic stratigraphy of a $400 \mathrm{~km}$-long fjord-shelf-slope transect, Kangerlussuaq margin, East Greenland. Quat. Sci. Rev., 29(25-26), 3359-3369 (doi: 10.1016/j.quascirev. 2010.06.006)

Dwyer JL (1995) Mapping tidewater glacier dynamics in East Greenland using Landsat data. J. Glaciol., 41(139), 584-595

Ettema J, Van den Broeke MR, Van Meijgaard E, Van de Berg WJ, Box JE and Steffen K (2010) Climate of the Greenland ice sheet using a high-resolution climate model: Part 1: evaluation. Cryos. Discuss., 4(4), 561-602 (doi: 10.5194/tcd-4-561-2010)

Funk M, Echelmeyer K and Iken A (1994) Mechanisms of fast flow in Jakobshavns Isbræ, West Greenland: Part II. Modeling of englacial temperatures. J. Glaciol., 40(136), 569-585

Holland DM, Thomas $\mathrm{RH}$, de Young B, Ribergaard $\mathrm{MH}$ and Lyberth B (2008) Acceleration of Jakobshavn Isbræ triggered by warm subsurface ocean waters. Nature Geosci., 1(10), 659-664 (doi: 10.1038/ngeo316)

Howat IM, Joughin IR and Scambos TA (2007) Rapid changes in ice discharge from Greenland outlet glaciers. Science, 315(5818), 1559-1561 (doi: 10.1126/science.1138478)

Howat IM, Joughin I, Fahnestock M, Smith BE and Scambos T (2008) Synchronous retreat and acceleration of southeast Greenland outlet glaciers 2000-2006: ice dynamics and coupling to climate. J. Glaciol., 54(187), 646-660 (doi: 10.3189/002214308786570908)

Howat IM, Box JE, Ahn Y, Herrington A and McFadden EM (2010) Seasonal variability in the dynamics of marine-terminating outlet glaciers in Greenland. J. Glaciol., 56(198), 601-613 (doi: 10.3189/002214310793146232)

Howat IM, Ahn Y, Joughin I, Van den Broeke MR, Lenaerts JTM and Smith B (2011) Mass balance of Greenland's three largest outlet glaciers, 2000-2010. Geophys. Res. Lett., 38(12), L12501 (doi: 10.1029/2011GL047565)

Iken A, Echelmeyer K, Harrison W and Funk M (1993) Mechanisms of fast flow in Jakobshavns Isbræ, West Greenland: Part I. Measurements of temperature and water level in deep boreholes. J. Glaciol., 39(131), 15-25

Jenkins A (2011) Convection-driven melting near the grounding lines of ice shelves and tidewater glaciers. J. Phys. Oceanogr., 41(12), 2279-2294 (doi: 10.1175/JPO-D-11-03.1)

Jenkins A, Nicholls KW and Corr HFJ (2010) Observation and parameterization of ablation at the base of Ronne Ice Shelf, Antarctica. J. Phys. Oceanogr., 40(10), 2298-2312 (doi: 10.1175/2010JPO4317.1)

Joughin I and 8 others (2008a) Ice-front variation and tidewater behavior on Helheim and Kangerdlugssuaq Glaciers, Greenland. J. Geophys. Res., 113(F1), F01004 (doi: 10.1029/ 2007JF000837)

Joughin I and 7 others (2008b) Continued evolution of Jakobshavn Isbræ following its rapid speedup. J. Geophys. Res., 113(F4), F04006 (doi: 10.1029/2008JF001023)

Luckman A, Murray T, de Lange R and Hanna E (2006) Rapid and synchronous ice-dynamic changes in East Greenland. Geophys. Res. Lett., 33(3), L03503 (doi: 10.1029/2005GL025428)

Murray T and 10 others (2010) Ocean regulation hypothesis for glacier dynamics in southeast Greenland and implications for ice sheet mass changes. J. Geophys. Res., 115(F3), F03026 (doi: 10.1029/2009JF001522)

Nick FM, Vieli A, Howat IM and Joughin I (2009) Large-scale changes in Greenland outlet glacier dynamics triggered at the terminus. Nature Geosci., 2(2), 110-114 (doi: 10.1038/ ngeo394)

O'Leary M (2011) Frontal processes on tidewater glaciers. (PhD thesis, University of Cambridge)

Price SF, Payne AJ, Howat IM and Smith BE (2011) Committed sealevel rise for the next century from Greenland ice sheet dynamics during the past decade. Proc. Natl Acad. Sci. USA (PNAS), 108(22), 8978-8983 (doi: 10.1073/pnas.1017313108)

Reeh N, Thomsen HH, Higgins AK and Weidick A (2001) Sea ice and the stability of north and northeast Greenland floating glaciers. Ann. Glaciol., 33, 474-480 (doi: 10.3189/ 172756401781818554)

Rignot E and Kanagaratnam P (2006) Changes in the velocity structure of the Greenland Ice Sheet. Science, 311(5673), 986-990 (doi: 10.1126/science.1121381)

Rignot E, Braaten D, Gogineni P, Krabill WB and McConnell JR (2004) Rapid ice discharge from southeast Greenland glaciers. Geophys. Res. Lett., 31(10), L10401 (doi: 10.1029/ 2004GL019474)

Rignot E, Box JE, Burgess E and Hanna E (2008) Mass balance of the Greenland ice sheet from 1958 to 2007. Geophys. Res. Lett., 35(20), L20502 (doi: 10.1029/2008GL035417)

Rignot E, Velicogna I, Van den Broeke MR, Monaghan A and Lenaerts J (2011) Acceleration of the contribution of the Greenland and Antarctic ice sheets to sea level rise. Geophys. Res. Lett., 38(5), L05503 (doi: 10.1029/2011GL046583)

Rudels B, Fahrbach E, Meincke J, Budéus G and Eriksson P (2002) The East Greenland Current and its contribution to the Denmark Strait overflow. ICES J. Mar. SCi., 59(6), 1133-1154 (doi: 10.1006/jmsc.2002.1284)

Seale A, Christoffersen P, Mugford RI and O'Leary M (2011) Ocean forcing of the Greenland Ice Sheet: calving fronts and patterns of retreat identified by automatic satellite monitoring of eastern 
outlet glaciers. J. Geophys. Res., 116(F3), F03013 (doi: 10.1029/ 2010JF001847)

Simmons A, Uppala S, Dee D and Kobayashi S (2006) ERA-Interim: new ECMWF reanalysis products from 1989 onwards. ECMWF Newsl. 110, 25-35

Sohn HG, Jezek KC and Van der Veen CJ (1998) Jakobshavn Glacier, West Greenland: 30 years of spaceborne observations. Geophys. Res. Lett., 25(14), 2699-2702 (doi: 10.1029/98GL01973)

Solomon S and 7 others eds (2007) Climate change 2007: the physical science basis. Contribution of Working Group I to the Fourth Assessment Report of the Intergovernmental Panel on Climate Change. Cambridge University Press, Cambridge

Straneo F and 7 others (2010) Rapid circulation of warm subtropical waters in a major glacial fjord in East Greenland. Nature Geosci., 3(33), 182-186 (doi: 10.1038/ngeo764)

Sutherland DA and Pickart RS (2008) The East Greenland Coastal Current: structure, variability, and forcing. Progr. Oceanogr., 78(1), 58-77 (doi: 10.1016/j.pocean.2007.09.006)
Syvitski JPM, Andrews JT and Dowdeswell JA (1996) Sediment deposition in an iceberg-dominated glacimarine environment, East Greenland: basin fill implications. Global Planet. Change, 12(1-4), 251-270

Thomas RH and 8 others (2000) Substantial thinning of a major east Greenland outlet glacier. Geophys. Res. Lett., 27(9), 1291-1294 (doi: 10.1029/1999GL008473)

Van Angelen JH, Van den Broeke MR and Van de Berg WJ (2011) Momentum budget of the atmospheric boundary layer over the Greenland ice sheet and its surrounding seas. J. Geophys. Res., 116(D10), D10101 (doi: 10.1029/2010JD015485)

Van den Broeke $M$ and 8 others (2009) Partitioning recent Greenland mass loss. Science, 326(5955), 984-986 (doi: 10.1126/science.1178176)

Van Meijgaard E and 6 others (2008) The KNMI regional atmospheric climate model RACMO version 2.1. Royal Netherlands Meteorological Institute (KNMI), De Bilt (KNMI Tech. Rep. TR-302) 